\title{
PERLINDUNGAN HUKUM BAGI KONSUMEN DALAM TRANSAKSI E-COMMERCE
}

\author{
Dianne Eka Rusmawati \\ Dosen Bagian Keperdataan Fakultas Hukum Universitas Lampung \\ Email : dianne_eka_rusmawati@fh.unila.ac.id
}

\begin{abstract}
Abstrak
Mengetahui dan memahami mengenai perlindungan hukum bagi konsumen dalam transaksi e-commerce adalah tujuan yang hendak dicapai. Berdasarkan pendekatan normatif, perlindungan hokum bagi konsumen dalam transaksi $e$-commerce dapat dilihat berdasarkan proses transaksinya, yaitu Proses transaksi menggunakan media on-line secara keseluruhan atau proses transaksinya saja yang menggunakan media on-line tapi pembayarannya dilakukan secara manual. Bentuk Perlindungan hukum bagi konsumen dalam transaksi e-commerce diatur dalam ketentuan Pasal 4 huruf $b$ dan c UUPK dan Ps 2 serta Pasal 9 UUITE.
\end{abstract}

Kata Kunci: perlindungan hukum, konsumen, e-commerce

\section{Latar Belakang}

Perkembangan transaksi elektronik tidak terlepas dari laju pertumbuhan internet, karena transaksi elektronik berjalan melalui jaringan internet.Pertumbuhan pengguna internet yang demikian pesatnya merupakan suatu kenyataan yang membuat internet menjadi salah satu media yang efektif bagi pelaku usaha untuk memperkenalkan dan menjual barang atau jasa ke calon konsumen dari seluruh dunia. ${ }^{1}$

Dapat dikatakan, bahwa kemajuan dan keunggulan teknologi komunikasi dan informasi telah melahirkan model transaksi baru di dunia perdagangan dan bisnis yaitu e-commerce transaction.E-commerce merupakan model bisnis modern yang non face (tidak menghadirkan pelaku bisnis secara fisik) dan non-

\footnotetext{
${ }^{1}$ Abdul Halim Barkattulah, Bentuk Perlindungan Hukum Bagi Konsumen Dalam Penyelesaian Sengketa Transaksi Elektronik Internasional menurut UU No 11 Tahun 2008,Jurnal Hukum Bisnis Vol 29 No 1 Tahun 2010, hlm 51.
}

sign (tidak memakai tanda tangan asli).

E-commerce adalah kegiatankegiatan bisnis yang menyangkut konsumen (consumers), manufaktur (manufacturers), service providers, dan pedagang perantara (intermediaries) dengan menggunakan jaringan-jaringan computer (computer networks), yaitu E-commerce sudah meliputi seluruh spectrum kegiatan komersial. $^{2}$ Menurut World Trade Organization(WTO), cakupan ecommerce meliputi bidang produksi, distribusi, pemasaran, penjualan, dan pengiriman barang atau jasa melalui cara elektronik. Julian Ding dalam bukunya E-commerce : Law and Practice, seperti dikutip oleh Ninik Suparni memberikan definisi ecommerce sebagai berikut.

Elektronik commerce,or ecommerce as it is also known, is a commercial transaction between a vendor and a purchaser or parties in

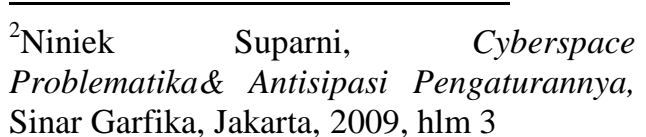
Sinar Garfika, Jakarta, 2009, hlm 3 
similar contractual relationship for the supplay of goods, services or the acquisition of "rights". This commercial transaction is executed or entered into in an electronic medium (or digital medium) where the physical presence of the parties is not required, and the medium exist in a public network or system as apposed to a private network(closed system). The public network or system must be considered an open system (e.g.the Internet or the World Wide Web). The transactions are concluded regardiess of nation boundaries or local requirements.

Sementara Kamels K Bajaj dan Debjani Nag menyatakan bahwa e-commerce adalah pertukaran informasi bisnis tanpa menggunakan kertas (the paperless exchange of business information), melainkan melalui EDI (Elektronik Data Exchange) E-mail,EBB (Elektronic Bulletin Board), Electronic Fund Transfer dan teknologi-teknologi lainnya yang menggunakan jasa jaringan(net). ${ }^{3}$

Secara singkat e-commerce dapat dideskripsikan sebagai suatu bentuk bisnis modern melalui sarana internet. Di Indonesia, fenomena ecommerce ini sudah dikenal sejak tahun 1996 dengan munculnya situs http://www.sanur.com sebagai took buku online pertama. Meski belum terlalu popular, pada tahun 1996 tersebut mulai bermunculan berbagai situs yang melakukan e-commerce.

Sepanjang tahun 1997-1998 eksistensi e-commerce di Indonesia sedikit terabaikan karena krisis ekonomi namun di tahun 1999 hingga saat ini kembali menjadi fenomena yang menarik perhatian meski tetap terbatas pada masyarakat

${ }^{3}$ Ibid, hlm 32 yang mengenal teknologi. Dalam praktek bisnis ini, karena para pihak (pembeli maupun penjual) tidak bertemu secara langsung (face to face) dalam melakukan transaksi bisnisnya, kemungkinan terjadi permasalahan-permasalahan hukum terutama mengenai aspek perlindungan konsumennya sangat mungkin terjadi, sebagai contoh ketika seorang konsumen berbelanja atau bertransaksi melalui internet, situasi yang terjadi akan sangat berbeda ketika konsumen berbelanja ke pasar tradisional/konvensional.

Bertransaksi atau berbelanja di pasar tradisional/konvensional, ketika terjadi seorang konsumen merasa dirugikan atas perbuatan pelaku usaha/penjual, maka konsumen dapat segera melakukan complain, namun ketika seorang konsumen bertransaksi melalui internet, ketika terjadi perbuatan curang oleh pelaku usaha atau penjual,misalnya barang yang dikirimkan oleh pelaku usaha tidak sesuai dengan pesanan konsumen, barang yang dibeli oleh konsumen tidak dikirim, barang dikirim tetapi terlambat, barang yang dikirim rusak/cacat, dan lain-lain, maka biasanya sulit bagi konsumen untuk melakukan complain kepada pelaku usaha atau penjual yang dapat dikarenakan oleh beberapa sebab, misalkan konsumen tidak mengetahui keberadaan pelaku usaha, atau pelaku usaha tidak menerima complain setelah barang di kirimkan atau bahkan ada itikad tidak baik dari pelaku usaha yang mengatakan bahwa uang pembayaran belum diterima pelaku usaha dan lain-lain.

Lemahnya posisi konsumen seringkali dimanfaatkan oleh pelaku usaha untuk memperoleh keuntungan 
yang sebesar-besarnya dari konsumen.Faktor ketidak tahuan konsumen, tidak jelasnya informasi terhadap barang/jasa yang diberikan pelaku usaha,tidak pahamnya konsumen pada mekanisme transaksi menjadi factor penyebab lemahnya kedudukan konsumen. Oleh karena itu, dalam rangka menciptakan iklim berusaha yng sehat bagi konsumen dalam melakukan transaksi perdagangan melalui e-commerce, maka perlu diupayakan suatu bentuk pengaturan hukum yang baru sekaligus memadai yang mampu mengatur segala aktivitasnya. ${ }^{4}$

Ketika seorang konsumen mengkonsumsi atau menggunakan suatu produk barang ataupun jasa, maka setiap konsumen pasti menginginkan adanya kepuasan terhadap produk tersebut,minimal, konsumen menginginkan adanya informasi yang jelas atas produk yang akan dibeli, keyakinan bahwa produk yang dibeli tidak berbahaya bagi kesehatan dan aman bagi jiwanya, produk yang dibeli cocok dan sesuai dengan keinginannya, baik segi kualitas maupun harga, konsumen tahu cara penggunaannya, ada garansi dari produk yang dibelinya.Namun kenyataan yang muncul, seringkali konsumen tidak memperoleh apa yang diharapkannya secara maksimal sehingga akibatnya konsumen merasa dirugikan.

Berdasarkan uraian tersebut bagaimana bentuk perlindungan hukum bagi konsumen dalam transaksi e-commerce?

4 Elisatris Gultom, Cyber Law: Suatu Pengantar Perlindungan Konsumen Dalam Transaksi Perdagangan Melalui Electronic Commerce, Elips, Bandung, hlm 55

\section{Pembahasan}

\subsection{Para pihak dalam Transaksi E-Commerce}

Transaksi E-Commerce melibatkan para pihak, baik pihak yang terlibat secara langsung maupun pihak yang tidak terlibat secara langsung. Untuk menentukan siapakah para pihak yang terlibat secara langsung dan para pihak yang tidak terlibat secara langsung dapat dilihat dari proses transaksi yang dilakukan, yaitu apakah semua proses transaksi dilakukan secara online atau hanya beberapa tahap saja yang dilakukan secara on-line. Berdasarkan hasil penelitian, apabila seluruh transaksi dilakukan secara on-line, maka pihak-pihak yang terlibat terdiri dari :

\section{Penjual/merchant}

Adalah perusahaan/produsen yang menawarkan produknya melalui internet. Untuk menjadi penjual/merchant, maka seseorang harus mendaftarkan diri dalam merchant account pada sebuah bank, tentunya ini dimaksudkan agar penjual/merchant dapat menerima pembayaran dari pembelidalam bentuk credit card. dalam Pasal 1 Ayat (6) UUITE penjual/merchant adalah penyelenggara sistem elektronik pengertiannya: "Penyelenggaraan Sistem Elektronik adalah pemanfaatan Sistem Elektronik oleh penyelenggara negara, Orang, Badan Usaha, dan/atau masyarakat".

\section{Pembeli/card holder}

Adalah orang-orang yang ingin memperoleh produk (barang/jasa) melalui pembelian secara online. Pembeli/card holder yang akan 
berbelanja di internet dapat berstatus perorangan atau perusahaan. Apabila konsumen merupakan perorangan, maka yang perlu diperhatikan dalam transaksi elektronik adalah bagaimana sistem pembayaran yang digunakan, apakah pembayaran dilakukan dengan mempergunakan credit card (kartu kredit) atau dimungkinkan pembayaran dilakukan secara manual/cash. Hal ini penting untuk diketahui, mengingat tidak semua konsumen yang akan berbelanja di internet adalah pemegang kartu kredit/card holder. Pemegang kartu kredit (card Holder) adalah orang yang namanya tercetak pada kartu kredit yang dikeluarkan oleh penerbit berdasarkan perjanjian yang dibuat. dalam Pasal 1 Ayat (6) UUITE pembeli/card holder jugaadalah penyelenggara sistem elektronik, yaitu: "Penyelenggaraan Sistem Elektronik adalah pemanfaatan Sistem Elektronik oleh penyelenggara negara, Orang, Badan Usaha, dan/atau masyarakat".

\section{Perantara penagihan/Acquirer}

Adalah pihak perantara penagihan (antara penjual dan penerbit) dan perantara pembayaran (antara pemegang dan penerbit). Perantara penagihan adalah pihak yang meneruskan penagihan kepada penerbit berdasarkan tagihan yang masuk kepadanya yang diberikan oleh penjual barang/jasa. Pihak perantara pembayaran antara pemegang dan penerbit adalah bank dimana pembayaran kartu kredit dilakukan oleh pemilik kartu kredit/card holder, selanjutnya bank yang menerima pembayaran ini akan mengirimkan uang pembayaran tersebut kepada penerbit kartu kredit. Dikenal juga sebgai penerima seperti yang diatur dalam Pasal 1 Ayat (19) UUITE "Penerima adalah subjek hukum yang menerima Informasi Elektronik dan/atau Dokumen Elektronik dari Pengirim".

\section{Penerbit kartu kredit/Issuer}

Adalah perusahaan credit card yang menerbitkan kartu atau perusahan pembayaran internet yang memiliki kewenangan untuk menerbitkan kredit, Di indonesia ada beberapa lembaga yang diijinkan untuk menerbitkan kartu kredit, yaitu:

a. Bank dan lembaga keuangan bukan bank. Tidak semua bank dapat menerbitkan credit card, hanya bank yang telah memperoleh ijin dari Card International, dapat menerbitkan credit card, seperti Master dan Visa card;

b. Perusahaan non bank yang membuat perjanjian dengan perusahaan yang ada di luar negeri;

c. Perusahaan yang membuka cabang dari perusahaan induk yang ada di luar Negeri.

Penerbit kartu kredit dikenal sebagai pengirim, menurut Pasal 1 Ayat (18) UUITE "Pengirim adalah subjek hukum yang mengirimkan Informasi Elektronik dan/atau Dokumen Elektronik".

\section{Certification Authorities}

Adalah pihak ketiga yang netral yang memegang hak untuk mengeluarkan sertifikasi kepada penjual/merchant, kepada penerbit kartu kredit/issuer, perantara penagihan/acquirer, penyedia layanan payment gateway dan dalam 
beberapa hal diberikan kepada card holder.

Dalam Undang-Undang Transaksi Elektonik Indonesia pihak ini dibagi menjadi dua yaitu:

a. Penyelenggara Sertifikasi Elektronik yang diatur pada Pasal 1 Ayat (10) UUITE "Penyelenggara Sertifikasi Elektronik adalah badan hukum yang berfungsi sebagai pihak yang layak dipercaya, yang memberikan dan mengaudit Sertifikat Elektronik",

b. Lembaga Sertifikasi Keandalan yang diatur dalam Pasal 1 Ayat (11) UUITE "Lembaga Sertifikasi Keandalan adalah lembaga independen yang dibentuk oleh profesional yang diakui, disahkan, dan diawasi oleh Pemerintah dengan kewenangan mengaudit dan mengeluarkan sertifikat keandalan dalam Transaksi Elektronik".

Jika transaksi E-Commerce tidak sepenuhnya dilakukan secra on-line dengan kata lain hanya proses transaksinya saja yang on-line sementara pembayaran tetap dilakukan secara manual/cash maka para pihak yang terlibat di dalamnya meliputi :

1. Penjual/merchant

Adalah perusahaan/produsen yang menawarkan produknya melalui internet. Untuk menjadi penjual/merchant, maka seseorang harus mendaftarkan diri dalam merchant account pada sebuah bank, tentunya ini dimaksudkan agar penjual/merchant dapat menerima pembayaran dari pembelidalam bentuk credit card. dalam Pasal 1 Ayat (6)
UUITE penjual/merchant adalah penyelenggara sistem elektronik pengertiannya: Penyelenggaraan Sistem Elektronik adalah pemanfaatan Sistem Elektronik oleh penyelenggara negara, Orang, Badan Usaha, dan/atau masyarakat".

\section{Pembeli/card holder}

Adalah orang-orang yang ingin memperoleh produk (barang/jasa) melalui pembelian secara online. Pembeli/card holder yang akan berbelanja di internet dapat berstatus perorangan atau perusahaan. Apabila konsumen merupakan perorangan, maka yang perlu diperhatikan dalam transaksi elektronikadalah bagaimana sistem pembayaran yang digunakan, apakah pembayaran dilakukan dengan mempergunakan credit card (kartu kredit) atau dimungkinkan pembayaran dilakukan secara manual/cash. Hal ini penting untuk diketahui, mengingat tidak semua konsumen yang akan berbelanja di internet adalah pemegang kartu kredit/card holder. Pemegang kartu kredit (card Holder) adalah orang yang namanya tercetak pada kartu kredit yang dikeluarkan oleh penerbit berdasarkan perjanjian yang dibuat. dalam Pasal 1 Ayat (6) UUITE pembeli/card holder jugaadalah penyelenggara sistem elektronik, yaitu: "Penyelenggaraan Sistem Elektronik adalah pemanfaatan Sistem Elektronik oleh penyelenggara negara, Orang, Badan Usaha, dan/atau masyarakat".

3. Jasa Pengiriman atau ekspedisi 


\subsection{Perlindungan hukum bagi Konsumen dalam Transaksi E-Commerce}

Perlindungan hokum merupakan cara untuk melindungi konsumen yang diberikan oleh hukum atau Undang-undang untuk mencegah adanya pelanggaran atau hal-hal yang dapat merugikan kepentingan konsumen. Dalam penelitian ini, konsumen pengguna transaksi E-Commerce mendapatkan perlindungan hokum berdasarkan ketentuan Peraturan PerUndangundangan yaitu Undang-undang Perlindungan Konsumen (UUPK), Undang-Undang Informasi dan Transaksi Elektronik(UUITE). Dengan demikian berikut ini akan diuraikan perlindungan hokum kepada konsumen berdasarkan Peraturan PerUndang-undangan tersebut diatas, yaitu :

1. Perlindungan Hukum Ditinjau dari UUPK. Konsumen dalam berbagai segi merupakan pihak yang lemah kedudukannya bila dibandingkan pelaku usaha, konsumen seringkali tidak memiliki posisi tawar jika berhadapan dengan pelaku usaha. Oleh karena itu, diperlukan suatu aturan yang dapat melindungi kepentingan konsumen agar tidak dirugikan atu diperlakukan sewenangwenang oleh pelaku usaha. UUPK menjami adanya epastian hokum untuk memberikan perlindungan kepada konsumen seperti tercantum dalam Pasal 1 Angka(1) UUPK. UUPK memberikan perlindungan kepada setiap konsumen yang merasa hak-haknya dilanggar atau dirugikan oleh pelaku usaha. Dalam UUPK ditentukan secara rinci hak-hak konsumen yang berlaku pula bagi konsumen pengguna transaksi elektronik/E-Commerce.

Berdasarkan ketentuan Pasal 4 UUPK tersebut, maka dalam hubungannnya dengan konsumen pengguna transaksi E-Commerce yang dilanggar oleh pelaku usaha atau penjual adalah sebagai berikut :

a. Pasal 4 huruf $b$

Hak untuk memilih barang dan atau jasa serta mendapatkan barang barang dan/atau jasa tersebut sesuai dengan nilai tukar dan kondisi serta jaminan yang dijanjikan.

Berdasarkan pasal 4 huruf $b$ tersebut, dalam kaitannya dengan konsumen pengguna transaksi ECommerce maka pihak pelaku usaha atau penjual harus menyediakan barang sesuai dengan nilai tukar dan kondisi serta jaminan yang dijanjikan.

b. Pasal 4 huruf c

Pasal 4 huruf $\mathrm{c}$ menentukan bahwa konsumen berhak atas informasi yang benar, jelas, dan jujur mengenai kondisi dan jaminan barang dan/atau jasa. Pelaku usaha atau penjual dalam transaksi ECommerce sebaiknya memberikan keterangan secara jelas mengenai kondisi barang atau spesifikasi barang dan keterangan - keterangan lain yang berkaitan dengan barang yang dijual/diperdagangkannya.Hal ini penting dilakukan supay konsumen mengetahui secara jelas kondisi dari barang yang diperdagangkan untuk akhirnya dapat memutuskan apakah membeli atau tidak barang tersebut berdasarkan keterangan-keterangan yang tersedia. 
Dalam UUPK, di samping mengatur hak-hak konsumen, diatur pula kewajiban pelaku usaha sebagaimana ditentukan dalam Pasal 7 UUPK antara lain yang berkenaan dengan perlindungan hokum bagi konsumen pengguna transaksi ECommerce yaitu :

a. Aspek hokum perlindungan konsumen dalam ketentuan Pasal 7 huruf $b$ menyebutkan bahwa pelaku usaha berkewajiban memberikan informasi yang benar, jelas dan jujur mengenai kondisi dan jaminan barang dan/atau jasa serta memberikan penjelasan penggunaan, perbaikan dan pemeliharaan. Dalam hal ini penjual wajibmemberikan keterangan secara jelas mengenai kondisi barang atau spesifikasi barang dan keterangan - keterangan lain yang berkaitan dengan barang yang dijual/diperdagangkannya. Hal ini penting dilakukan supaya konsumen mengetahui secara jelas kondisi dari barang yang diperdagangkan untuk akhirnya dapat memutuskan apakah membeli atau tidak barang tersebut berdasarkan keteranganketerangan yang tersedia.

b. Pasal 7 huruf d. Pasal 7 huruf d menyatakan bahwa pelaku usaha berkewajiban untuk menjamin mutu barang dan/atau jasa yang diproduksi dan atau diperdagangkan berdasarkan ketentuan standar mutu barang dan/ atau jasa yang berlaku. Berkaitan dengan konsumen pengguna transaksi E-Commerce maka pelaku usaha atau penjual wajib menjamin mutu barang dan atau jasa yang diproduksi sesuai dengan standar mutu barang dan atau jasa yang berlaku serta sesuai degan kondisi barang yang ditawarkan.

2. Perlindungan Hukum Ditinjau dari Undang- Undang Informasi dan Transaksi Elektronik

Undang-Undang No 11 Tahun 2008 Tentang Informasi dan Transaksi Elektronik mengatur bebrapa ketentuan yang merupakan bentuk perlindungan hokum kepada konsumen pengguna transaksi $E$ Commerce. Bentuk perlindungan hukum tersebut adalah sebagai berikut :

\section{a. Pasal 2 UUITE}

Undang-undang ini berlaku untuk setiap orang yang melakukan perbuatan hukum sebagaimana diatur dalam Undang-undang ini, baik yang berada di wilayah hukum Indonesia maupun di luar wilayah hukum Indonesia yang memiliki akibat hukum di Indonesia atau di luar wilayah hukum Indonesia yang merugikan kepentingan Indonesia.

\section{b. Pasal 9 UU ITE}

Dalam pasal ini pelaku usaha yang menawarkan produk melalui system elektronik harus menyediakan informasi yang lengkap dan benar berkaitan dengan syarat kontrak, produsen dan produk yang ditawarkan. Yang dimaksud dengan informasi yang lengkap dan benar adalah :

1. Informasi yag memuat identitas serta status subjek hokum dan kompetensinya baik sebagai produsen, pemasok, penyelenggara ataupun perantara. 
2. Informasi lain yang menjelaskan hal tertentu yang menjadi syarat sahnya perjanjian serta menjelaskan barang dan atau jasa dalam yang ditawarkan seperti nama, alamat dan deskripsi barang/jasa.

\section{Penutup}

\subsection{Simpulan}

1. Pihak-pihak yang terlibat dalam transaksi E-Commerce jika transaksinya dilakukan sepenuhnya secara on-line terdiri dari : a) Penjual (merchant); b) Konsumen (card holder); c) Acquirer atau pihak perantara penagihan; d) Issuer atau perusahaan credit card yang menerbitkan kartu; e) Certification authorities atau pihak ketiga yang memegang hak untuk mengeluarkan sertifikasi kepada merchant

2. Pihak-pihak yang terlibat dalam transaksi E-Commerce jika transaksinya saja yang on-line sementara pembayaran dilakukan secara manual terdiri dari : a) Penjual danb) Konsumen

3. Bentuk Perlindungan Hukum kepada Konsumen dalam UUPK yaitu a) berhak untuk memilih barang dan atau jasa serta mendapatkan barang barang dan/atau jasa tersebut sesuai dengan nilai tukar dan kondisi serta jaminan yang dijanjikan; b) pihak pelaku usaha atau penjual menyediakan barang sesuai dengan nilai tukar dan kondisi serta jaminan yang dijanjikan; c) konsumen berhak atas informasi yang benar, jelas, dan jujur mengenai kondisi dan jaminan barang dan/atau jasa; Pelaku usaha atau penjual dalam transaksi E-Commerce sebaiknya memberikan keterangan secara jelas mengenai kondisi barang atau spesifikasi barang dan keterangan - keterangan lain yang berkaitan dengan barang yang dijual/diperdagangkannya; d) Bentuk Perlindungan Hukum bagi Konsumen dalam UUITE yaitu Pasal 2 UUITE Undangundang ini berlaku untuk setiap orang yang melakukan perbuatan hukum sebagaimana diatur dalam Undang-undang ini, baik yang berada di wilayah hukum Indonesia maupun di luar wilayah hukum Indonesia yang memiliki akibat hukum di Indonesia atau di luar wilayah hukum Indonesia yang merugikan kepentingan Indonesia; e) Dalam pasal ini pelaku usaha yang menawarkan produk melalui system elektronik harus menyediakan informasi yang lengkap dan benar berkaitan dengan syarat kontrak, produsen dan produk yang ditawarkan. 


\section{Daftar Pustaka}

Barkatulah, Abdul Halim, Bentuk Perlindungan Hukum Bagi Konsumen Dalam Penyelesaian Sengketa Transaksi Elektronik Internasional menurut UU No 11 Tahun 2008, Jurnal Hukum Bisnis Vol 29 No 1 Tahun 2010

Kristiyanti, dan Celina Tri Siwi, Hukum Perlindungan Konsumen, Sinar Grafika, Jakarta, 2009

Muhammad, Abdulkadir, Hukum Dan Penelitian Hukum, Citra Aditya Bakti, Bandung 2006

Sidabalok, Janus, Hukum Perlindungan Konsumen di Indonesia, Daya Widya, Jakarta, 2006

Suparni, Niniek, Cyberspace Problematika\& Antisipasi Pengaturannya, Sinar Garfika, Jakarta, 2009.

Sasongko, Wahyu, Hukum Perlindungan Konsumen, Universitas Lampung, 2010.

UU No 8 Tahun 1999 Tentang Perlindungan Konsumen

UU No 11 Tahun 2008 tentang Informasi dan Transaksi Elektronik 